\title{
MaRTa CZyŻEWSKa
}

Uniwersytet Pedagogiczny w Krakowie, Polska

Pedagogical University of Cracow, Poland

\section{ARKADIUSZ LEWICKI}

Wyższa Szkoła Informatyki i Zarządzania z siedzibą w Rzeszowie, Polska

University of Information Technology and Management in Rzeszow, Poland

\section{Badanie innowacyiności gospodarek Europy w latach 2010-2016 z wykorzystaniem informatycznych narzędzi doboru modelu, estymatorów i parametrów analizy danych}

\section{Research on the Innovation of European Economies in 2010-2016 Using IT Tools for Model Selection, Estimators and Data Analysis Parameters}

Streszczenie: Artykuł prezentuje badanie zmienności przestrzennej parametrów będących głównymi wskaźnikami innowacyjności na przykładzie danych European Innovation Scoreboard (EIS) za okres 2010-2016. Zastosowano autorskie narzędzie oceny struktury i wejściowych wektorów danych, doboru modelu analizy korelacji wprowadzonych danych oraz oceny parametrów wybranego modelu. Dzięki temu dokonano pozycjonowania ujętych w indeksie EIS krajów Europy pod względem aktywności innowacyjnej, w szczególności w prowadzeniu działalności $B+R$, procesie patentowania wynalazków oraz wdrażania innowacji. Autorzy artykułu, przy wykorzystaniu opracowanego narzędzia, podjęli próbę oszacowania wartości nakładów na $\mathrm{B}+\mathrm{R}$, intensywności zaangażowania przedsiębiorstw w działalność innowacyjną, niezbędnego do osiągnięcia co najmniej średniego poziomu innowacyjności liczonego dla krajów objętych indeksem EIS. Uzyskane wyniki mogą stanowić podstawę rekomendacji dla twórców polityki innowacyjnej, decydujących o zakresie wspierania działalności innowacyjnej przez rządy państw. Przeprowadzone analizy przedstawiają ocenę efektywności wydatków publicznych i prywatnych na działalność B+R, co - na bazie otrzymanych wyników i ocen porównawczych - pozwala sformułować kierunki i zakres zaangażowania publicznego w stymulowanie innowacyjności, warunkujące przyspieszenie rozwojowe polskiej gospodarki.

\begin{abstract}
The article presents the study of spatial variability of parameters being the main indicators describing innovativeness on the basis of European Innovation Scoreboard for the period 2010-2016. For this purpose we applied our own tool to assess the structure and input data vectors, and to select a correlation model for the input data and to assess the parameters of the selected model used. Thanks to this we positioned European countries in the EISin terms of innovative activity, in particular in conducting research and development, patenting of inventions and implementation of innovations. Using the developed tool we estimated the value of R\&D expenditures, the intensity of enterprises' involvement in innovative activity that are necessary to achieve at least the average level of innovation calculated for countries covered by the European Innovation Scoreboard. The results obtained may constitute recommendations for the innovation policy makers deciding on the scope of supporting innovative activities. The analyses carried out present an assessment of the effectiveness of public and private R\&D expenditures which are based on the results ob-
\end{abstract}


tained and comparative assessments and allow to formulate the directions and scope of public involvement in stimulating innovativeness that determines the acceleration of the Polish economy development.

Słowa kluczowe: algorytmy analizy przestrzennej struktury zależności składowych wektorów wejściowych; analiza dużych zbiorów danych; European Innovation Scoreboard; rankingi innowacyjności; wydatki na działalność B+R

Keywords: algorithms for spatial analysis of data vectors; big data analysis; European Innovation Scoreboard; innovativeness rankings; R\&D expenditures

Otrzymano: 19 grudnia 2017

Received: 19 December 2017

Zaakceptowano: 23 maja 2018

Accepted: 23 May 2018

\section{Sugerowana cytacja / Suggested citation:}

Czyżewska, M., Lewicki, A. (2018). Badanie innowacyjności gospodarek Europy w latach 2010-2016 z wykorzystaniem informatycznych narzędzi doboru modelu, estymatorów i parametrów analizy danych. Prace Komisji Geografii Przemysłu Polskiego Towarzystwa Geograficznego, 32(2), 21-37. https://doi.org/10.24917/20801653.322.2

\section{WSTĘP}

Artykuł ma na celu prezentację wykorzystania nowego podejścia z zastosowaniem uczenia nadzorowanego do oceny innowacyjności gospodarek Europy na przykładzie danych z European Innovation Scoreboard (EIS) za okres 2010-2016. Wykorzystując narzędzia informatyczne doboru właściwego modelu analizy przestrzennej struktury zależności wektorów danych, autorzy podjęli próbę określenia kierunku i siły związków między wybranymi wskaźnikami opisującymi innowacyjność gospodarek krajów Europy w obszarze prowadzenia działalności B+R, patentowania wynalazków, wdrażania innowacji wraz z oszacowaniem wartości poszczególnych parametrów pozwalającym pozycjonować kraje w rankingu krajów Europy objętych EIS.

W innowacyjności upatruje się sił napędzających rozwój gospodarczy, stąd jest ona przedmiotem zainteresowań zarówno praktyków, jak i badaczy. Złożoność zjawiska stanowi wyzwanie dla podejmujących się jego pomiaru. Silna korelacja między innowacyjnością a rezultatami ekonomicznymi potwierdza wysoką rangę innowacyjności w rozwoju gospodarczym. Analiza poziomu innowacyjności krajów Europy pozwala poczynić spostrzeżenia do formułowania wniosków i rekomendacji dla Polski, której pozycja w wielu rankingach jest wciąż niska.

\section{DEFINICJE INNOWACJI I INNOWACYJNOŚCI ORAZ DETERMINANTY INNOWACYJNOŚCI GOSPODAREK}

W literaturze występuje wiele definicji innowacji oraz innowacyjności. Za prekursora w tej dziedzinie uważa się J.A. Schumpetera, który innowację określił jako „wprowadzenie do produkcji wyrobów nowych lub też udoskonalenie dotychczas istniejących, wprowadzenie nowej lub udoskonalonej metody produkcji, otwarcie nowego rynku, zastosowanie nowego sposobu sprzedaży lub zakupów, zastosowanie nowych surowców lub półfabrykatów, wprowadzenie nowej organizacji produkcji" (Schumpeter, 1960: 104). Ph. Kotler określa innowacją dobro, usługę lub pomysł, które ktoś postrzega jako nowe (Kotler, 1994: 15-28). P. Drucker podkreśla, że innowacja jest 
pracą zorganizowaną, systematyczną i racjonalną, czyli zorganizowanym procesem zarządzania ukierunkowanym na stymulowanie rozwoju innowacji oraz narzędziem przedsiębiorczości (Drucker, 1992: 36). Zagadnienia innowacji oraz innowacyjności gospodarki zostały szeroko omówione w literaturze (m.in.: Griffin, 1996; Pomykalski, 2001; Weresa, 2002; 2012; 2014 Śpionek, 2010; Karlik, 2012; Zioło, Rachwał, 2012; Czerniak, 2013).

Niezbędny dla rozwijania innowacyjnej gospodarki jest sprzyjający klimat pobudzający kreatywność i przedsiębiorczość (Birch, 1987: 140-165). Badania (Kozłowski, 2015: 609-628) wykazują bardzo wysoką korelację między poziomem innowacyjności a rezultatami ekonomicznymi poszczególnych krajów. Powstaje wiele podejść w zakresie tworzenia sumarycznych wskaźników mierzenia innowacyjności i kreatywności jako czynników warunkujących rozwój gospodarek krajów, np. Global Creativity Index (2015), Global Innovation Index (2016), European Innovation Scoreboard (2017).

Z badań i analiz czynników współtworzących wskaźniki sumaryczne wynika, że w krajach najbardziej innowacyjnych udział publicznych wydatków w całkowitych wydatkach na B+R jest niewielki. Natomiast analiza struktury przedmiotowej wydatków na działalność B+R pokazuje, że kraje OECD i UE-28 wydają mniej na badania podstawowe niż na badania stosowane i prace rozwojowe. Z kolei kraje mniej zamożne, o niższym poziomie rozwoju technologicznego i niższym poziomie innowacyjności, przeznaczają na badania podstawowe znacznie większą część inwestowanych środków (Tylec, 2015: 242-253).

Zważając na szacunki ekonomistów, którzy oceniają, że aż dwie trzecie wzrostu gospodarczego krajów rozwiniętych należy łączyć z wprowadzaniem innowacji, uzasadnione wydaje się od wielu lat postulowane zwiększenie rangi polityki innowacyjnej (Managing National Innovation Systems, 1999; Frascati Manual..., 2002; Dynamising National Innovation Systems, 2002; Oslo Manual, 2005; The Innovation Policy Platform, 2018).

\section{ZAANGAŻOWANIE PAŃSTWA A EFEKTYWNOŚĆ DZIAŁALNOŚCI BADAWCZO-ROZWOJOWEJ W ŚWIETLE DOTYCHCZASOWYCH BADAŃ}

Rola polityki państwa w stymulowaniu innowacyjnej gospodarki uwidacznia się przede wszystkim w zakresie wydatków publicznych na B+R. K. Polarczyk stwierdza, że jest to pochodna uwarunkowana ustrojem: im więcej w ustroju danego państwa pojawia się pierwiastków socjalizmu, a mniej liberalizmu, tym większe są rozmiary wydatków publicznych ogółem. W związku z tym Polska, obok Węgier, Szwecji i Francji, zalicza się do krajów UE o najwyższym tzw. poziomie opiekuńczości (Polarczyk, 2007: 1-2). T. Skica, odnosząc się do wydatków publicznych w ogóle, podkreśla, że trzeba je postrzegać przez pryzmat arbitralności rozmiarów i kierunków wydatkowanych środków, ich marnotrawstwa, a finalnie również tzw. efektu wypychania (Skica, 2011: 115-129). Analizując strukturę finansowania B+R, znaczny udział sektora publicznego skutkuje wypychaniem wydatków na ten cel w sektorze przedsiębiorstw (Zegarowicz, Wildowicz- Giegiel, 2017: 415-428).

Doświadczenia okresu transformacji systemowej pokazały jednakże, że zmniejszenie ingerencji państwa nie w każdej dziedzinie jest pożądane (Grosse, 2002: 26). Wyzwaniem toczących się od wielu lat dyskusji na temat uwarunkowań innowacyjności jest wskazanie optymalnego poziomu i pożądanych sposobów ingerencji państwa w gospodarkę, aby inwestycje dokonywane przez państwo były możliwie najbardziej 
Ryc. 1. Elastyczność wydatków na B+R w sektorze prywatnym a poziom subsydiowania państwa

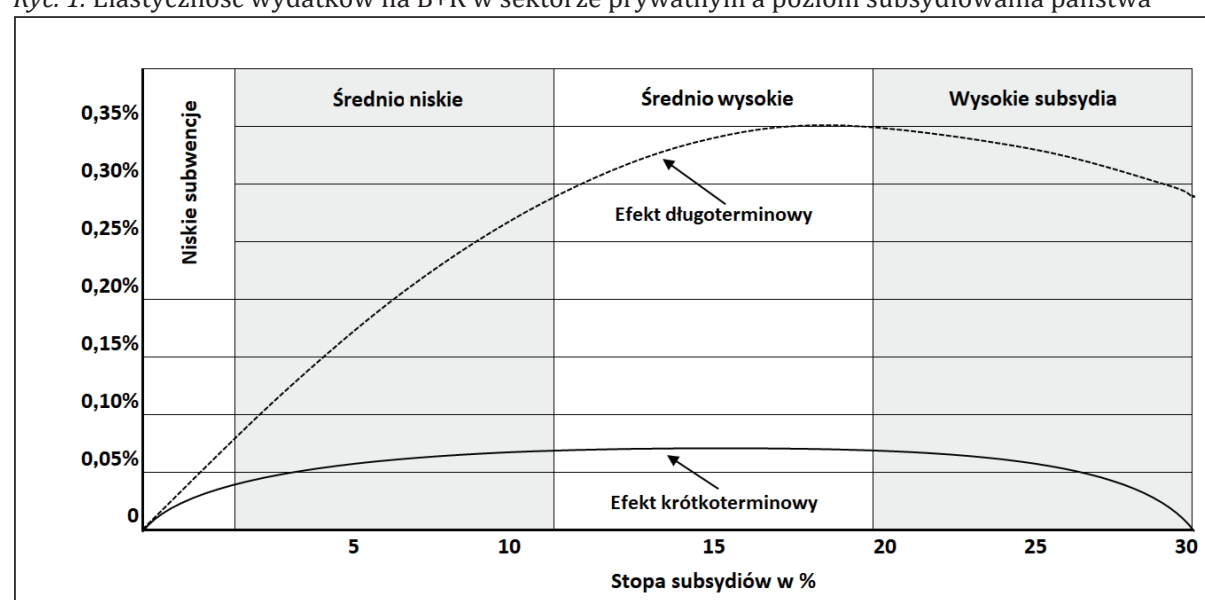

Źródło: Guellec. van Pottelsberghe de la Potterie (1999: 108)

efektywne i skutecznie zachęcały sektor prywatny do jak największej skali współfinansowania nakładów na innowacje, aby budować innowacyjną i konkurencyjną gospodarkę kraju.

Polityka proinnowacyjna realizowana jest pośrednio przez regulacje (zachęty podatkowe) oraz bezpośrednio przez dofinansowanie działalności innowacyjnej (subsydia). Każde państwo stoi przed problemem wyboru „mieszanki” narzędzi bezpośrednich i pośrednich (Shirley, 1994: 104). D. Guellec i B. van Pottelsberghe de la Potterie (1999: 95-122) wykazali stymulujący wpływ subsydiów oraz zachęt podatkowych na finansowanie działalności B+R przedsiębiorstw. Rządy państw powinny prowadzić stabilną długookresową politykę wspierania innowacyjnej działalności w przedsiębiorstwach, redukując w ten sposób niepewność i ryzyko, jakich doświadcza przedsiębiorca (ryc. 1).

Wydatki na B+R uważane są za czynnik zapewniający długookresową konkurencyjność, a zatem wzrost gospodarczy i zatrudnienie. Kraje, które M. Cincera, D. Czarnitzki, S. Thorwarth (2011: 131-139) uznali za najbardziej efektywne w zakresie publicznego wspierania działalności B+R, to: Australia, Kanada, Finlandia, Niemcy, Japonia, Holandia, Nowa Zelandia, Singapur, Szwajcaria i USA.

Stymulowanie innowacyjności stanowi ogromne wyzwanie, a cele ustanowione dla krajów UE, wynikające ze Strategii lizbońskiej, Strategii Europa 2020 (Komunikat Komisji Europa 2020, 2010), mierzone wskaźnikiem udziału nakładów na B+R w PKB na poziomie $3 \%$, nadal nie zostały osiągnięte.

Wdrażanie systemowych rozwiązań wymaga kompleksowego podejścia do pomiaru innowacyjności na poziomie mikro-, mezo- i makroekonomicznym oraz globalnym. Dlatego koniecznością jest opracowanie metodologii pomiaru, umożliwiającej trafną diagnozę oraz właściwe korygowanie podjętych działań.

\section{ZŁOŻONOŚĆ ZJAWISKA INNOWACYJNOŚCI WYZWANIEM DLA POMIARU}

Procesy tworzenia innowacji uległy wielu przemianom w ciągu ostatnich kilkudziesięciu lat. Innowacje są rezultatem współpracy sieciowej podmiotów, często 
funkcjonujących w różnych krajach (tzw. model innowacji piątej generacji; Jasiński, 1998: 13-14).

Analizując czynniki uznawane za determinanty innowacyjności, daje się zauważyć wysoki poziom złożoności zjawiska, bowiem według S. Kasprzyka (1980: 47) uwarunkowane jest ono: prawami przyrody, stanem wiedzy naukowej i wiedzy technicznej, bazą materiałowo-techniczną, poziomem organizacyjnym, wymaganiami użytkowników, czynnikami ekonomicznymi, socjologicznymi, psychologicznymi oraz społeczno-politycznymi.

W. Janasz i K. Kozioł (2007: 43-44) wskazali na różnorodność czynników otoczenia dalszego, warunkujących procesy kreacji i dyfuzji innowacji. Złożoność zjawiska innowacyjności rodzi wyzwania związane z doskonaleniem zestawów wskaźników pozwalających dokonywać syntetycznego pomiaru innowacyjności gospodarek i międzynarodowych porównań oraz opracowywać rankingi innowacyjności.

Komisja Europejska opracowała Europejski Ranking Innowacyjności, pozwalający mierzyć poziom innowacyjności gospodarek krajów UE. Metodyka oceny w zakresie doboru i grupowania wskaźników ewoluuje, co oznacza, że trwają poszukiwania nowego podejścia do oceny innowacyjności. Wskaźniki cząstkowe Europejskiego Rankingu Innowacyjności składają się na Sumaryczny Wskaźnik Innowacyjności (ang. Summary Innovation Index, SII).

Aby zbadać strukturę przestrzenną dostępnych zbiorów danych, a więc przeanalizować związki i zależności pomiędzy rozkładami dwóch lub więcej badanych cech dostępnych wektorów danych wejściowych, autorzy artykułu zastosowali autorskie narzędzie informatyczne LR Search Data. Pozwala ono na ocenę wartości oczekiwanej jednej zmiennej losowej na podstawie innej reprezentacji lub innych reprezentacji zmiennych, niezależnie od wielkości analizowanego zbioru danych. W odniesieniu do danych z EIS za lata 2010-2016 i poszukiwania dla nich zależności przyczynowo-skutkowych, okazało się, że oczekiwanym modelem, który dobrze uwidacznia zależności pomiędzy obserwowanymi zmiennymi, może być już model regresji liniowej z elementami stałymi, losowymi bądź mieszanymi. W odniesieniu do wskazanych zbiorów danych analiza współczynnika determinacji, będącego miarą dopasowania modelu regresji do danych, wykazała, że nawet w przypadku zastosowania modelu z elementami stałymi możemy wnioskować o kierunku i sile związku korelacyjnego pomiędzy badanymi elementami wektora danych. Rozwiązanie to zostało więc przyjęte jako bazowy model do przeprowadzenia badań zależności powiązań pomiędzy wieloma zmiennymi, aby można było prawidłowo zidentyfikować współzależności cech, od których zależy innowacyjność gospodarek europejskich.

\section{ANALIZA KORELACJI ZMIENNYCH W ODNIESIENIU DO BADANIA STRUKTURY PRZESTRZENNEJ DLA ZBIORÓW OBIEKTÓW EUROPEAN INNOVATION SCOREBOARD}

W obecnych czasach, gdy możliwości obliczeniowe komputerów są coraz większe, coraz częściej stosuje się też uogólnienia modeli liniowych, tak aby można było przeprowadzić analizę nawet złożonych relacji pomiędzy badanymi zmiennymi. Jednym z najlepiej sprawdzających się w tym obszarze narzędzi modelowania statystycznego jest regresja. Pozwala bowiem ona zarówno na dokonanie charakterystyki zależności pomiędzy zmiennymi objaśniającymi a zmienną objaśnianą, oszacowanie średniej 
wartości zmiennej objaśnianej w zależności od zmiennych objaśniających, jak i na wybór zmiennych istotnie zależnych od zmiennej objaśnianej. Dodatkowo taki model regresji możemy rozszerzyć na dowolny model liniowy z elementami stałymi, losowymi bądź mieszanymi w zakresie: jednokierunkowej analizy wariancji, dwukierunkowej analizy wariancji oraz analizy kowariancji.

Dokonana przez aplikację ocena współczynnika determinacji dla zbiorów danych z EIS za lata 2010-2016 wykazała, że już zastosowanie modelu regresji liniowej z elementami stałymi będzie wiązać się z oczekiwaną jakością dopasowania modelu liniowego. Model ten przyjęto więc za podstawowy w odniesieniu do badania korelacji pomiędzy zmiennymi wskazanych zbiorów danych, aby można było zidentyfikować czynniki zarówno stymulujące, jak i hamujące procesy innowacyjne.

W odniesieniu do struktury przestrzennej danych, wskazującej na zależność liniową pomiędzy badanymi zmiennymi, najlepszy miernikiem korelacji jest współczynnik korelacji liniowej Pearsona (1):

$$
r_{x y}=\frac{\sum_{i=1}^{k}\left(x_{i}-\bar{x}\right)\left(y_{i}-\bar{y}\right)}{\sqrt{\sum_{i=1}^{k}\left(x_{i}-\bar{x}\right)^{2} \sum_{j=1}^{r}\left(y_{j}-\bar{y}\right)^{2}}}=\frac{C(X, Y)}{\delta_{x} \delta_{y}}
$$

gdzie:

$x, y$ - to zmienne ilościowe,

$x_{i}$ - to wartość zmiennej $x$ dla obserwacji i,

$y_{i}$ - to wartość zmiennej $y$ dla obserwacji i,

$\mathrm{y}_{\mathrm{j}}$ - to wartość zmiennej $y$ dla obserwacji j,

$\bar{x}$ - oznacza średnią dla wektora $x$,

$\bar{y}$ - średnią dla wektora $y$,

$C(X, Y)$ - oznacza kowariancję $X$ i $Y$,

$\delta_{x} \delta_{y}$ - oznaczają odchylenia standardowe.

Jeżeli $r_{X Y}=0$, wtedy zmienne nie są skorelowane. Natomiast dla $0<r_{x y}<0,1$ mamy znikomą korelację, dla 0,1 $\leq r_{x y}<0,3$ mamy korelację słabą, dla 0,3 $\leq r_{x y}<0,5$ - korelację umiarkowaną, dla 0,5 $\leq r_{x y}<0,7$ - korelację wysoką, dla 0,7 $\leq r_{x y}<0,9$ - korelację bardzo wysoką, a dla $0,9 \leq r_{x y}<1$ - korelację, którą możemy określić jako korelację prawie pełną. Kwadrat scharakteryzowanego powyżej współczynnika korelacji nazywamy współczynnikiem determinacji. To on właśnie pozwala zbadać jakość dopasowania modelu liniowego, a więc określić stopień, w jakim zmiany cech objaśnianych mogą być wyjaśnione przez zmienne objaśniające. W przypadku badanych zbiorów zmiennych współczynnik ten już dla modelu regresji liniowej wyniósł 0,93, co oznacza, że zastosowanie już tego modelu wiąże się $\mathrm{z}$ wiarygodną i satysfakcjonującą analizą przyczynowo-skutkową.

Regresję liniową, która pozwala badać relację pomiędzy zmiennymi ilościowymi $x$ i $y$, możemy zapisać jako funkcję (2):

gdzie:

$$
y_{i}=a x_{i}+b+\varepsilon_{i}
$$

$x_{i}$ - to wartość zmiennej $x$ dla obserwacji $i$,

$y_{i}$ - to wartość zmiennej $y$ dla obserwacji $i$, 
$a, b$ - to współczynniki regresji liniowej, które informują, jaki jest przeciętny przyrost wartości zmiennej zależnej na jednostkę przyrostu wartości zmiennej niezależnej, $\varepsilon_{i}$ - to zakłócenie losowe o rozkładzie normalnym.

W procesie analizy przyjętego modelu badania korelacji pomiędzy zmiennymi najbardziej istotna jest odpowiedź, jak bardzo zmienna $y$ jest zależna od zmiennej $x$. Sprawdzenie tej zależności polega na testowaniu hipotez (3):

$$
\left\{\begin{array}{l}
H_{0}: r_{x y}=0 \\
H_{1}: r_{x y} \neq 0
\end{array}\right.
$$

Pierwsza z nich oznacza brak zależności, natomiast zależność niezerowa (drugi przypadek) daje podstawy do przyjęcia, że zależność pomiędzy zmienną $x$ i $y$ jest istotna. Funkcją testową korelacji jest zmienna losowa Studenta (stosowanego przy ocenie niepewności pomiaru, gdy nie znamy odchylenia standardowego) to $(n-2)$ stopniach swobody, wyrażona wzorem (4):

$$
t=\frac{r}{\sqrt{1-r^{2}}} \sqrt{n-2}
$$

dla próby $n$-elementowej, z uwzględnieniem współczynnika $r$, będącego estymatorem. Wartość krytyczną $t_{n-2, \alpha}$ odczytujemy z rozkładu Studenta (ryc. 2) dla wcześniej przyjętego poziomu istotności, oznaczonego jako $\alpha$.

W przypadku gdy obliczona wartość $t$ znajduje się w dwustronnym obszarze krytycznym $\left(-\infty,-t_{n-2, \alpha}\right),\left(t_{n-2, \alpha^{\prime}}+\infty\right)$, to $H_{0}$ należy odrzucić na korzyść hipotezy $H_{1}$.

Do oceny badania dokładności oszacowania zastosowanej funkcji regresji stosuje się analizę reszt (ryc. 3), czyli odchyleń realizacji zmiennych $Y$ i $X$, zaobserwowanych w próbie losowej, oraz wartości szacowanych, obliczanych ze wzoru (5):

$$
\hat{y}_{t}=a_{0}+a_{1} t, \text { dla } t=1,2, \ldots, i
$$

Wartości $e_{t}=$ nazywamy resztami modelu. Średni błąd szacunku informuje zaś o tym, jakie jest przeciętne odchylenie empirycznych wartości zmiennej objaśnianej od wartości teoretycznych otrzymanych z funkcji regresji. Stanowi go pierwiastek kwadratowy z wariancji resztowej. Wariancję dla zmiennej $y$ względem zmiennej $x$ obliczamy ze wzoru (6):

$$
\delta^{2}\left(z_{i}\right)=\frac{\sum_{i=1}^{n}\left(y_{i}-\hat{y}\right)^{2}}{n-2}
$$

natomiast dla zmiennej $x$ względem zmiennej $y$ ze wzoru (7):

gdzie:

$$
\delta^{2}\left(u_{i}\right)=\frac{\sum_{i=1}^{n}\left(x_{i}-\hat{x}\right)^{2}}{n-2}
$$

$i$ - oznacza próbę,

$x, y$ - oznaczają wartości zmiennych. 
Ryc. 2. Rozkład Studenta dla przyjętego poziomu istotności $\alpha$

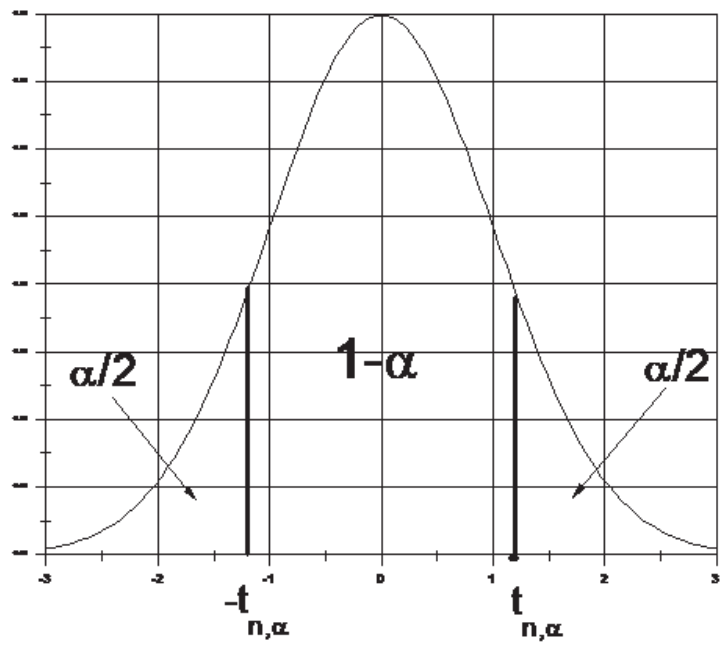

Źródło: opracowanie własne na podstawie: Efron, Hastie, Johnstone, Tibshirani (2004)

Ryc. 3. Analiza reszt dla zastosowanego modelu regresji liniowej

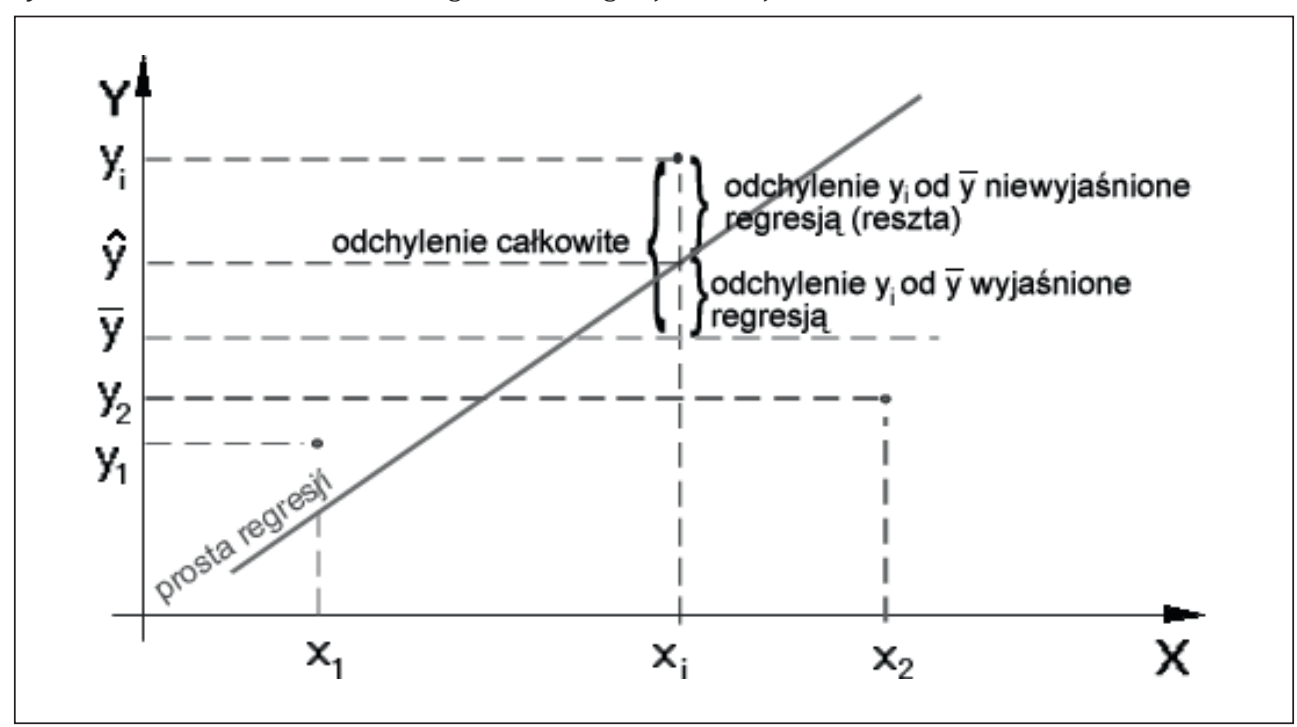

Źródło: opracowanie własne na podstawie Gnot (1994)

Wariancja reszt powinna być jednorodna i nie powinna zależeć funkcyjnie od wartości dopasowanych przez model.

W procesie analizy danych rzeczywistych obserwacja wystąpienia dużych reszt zawsze powinna zostać poprawnie zweryfikowana, ponieważ może to świadczyć o błędach w danych, o złym dopasowaniu modelu lub o niewłaściwej charakterystyce badanych zbiorów danych. 
Współczynniki $a$ i $b$ regresji liniowej wskazane we wzorze (2) można dobierać i oceniać, stosując rozmaite metody estymacji. Zastosowane zaś w aplikacji informatycznej metody estymacji to: metoda najmniejszych kwadratów oraz metoda największej wiarygodności. W przypadku pierwszej z nich estymatory znajduje się poprzez minimalizację kwadratu różnicy pomiędzy wartościami y a wartościami $\hat{y}$. Minimalizowaną wartość nazywa się zaś błędem kwadratowym. Metoda największej wiarygodności bazuje na logarytmie funkcji wiarygodności. W przypadku maksymalizacji tej funkcji, ze względu na współczynniki regresji, jest to równoważne minimalizacji sumy kwadratów reszt.

Przeprowadzone przez autorów doświadczenia wykazały, że zarówno estymator najmniejszych kwadratów, jak i estymator największej wiarygodności, sprawdzają się bardzo dobrze, jeżeli zakłócenie losowe ma średnią wynoszącą zero, stałą wariancję, a poszczególne zakłócenia losowe są niezależne.

\section{WYNIKI BADAŃ}

Przeprowadzone analizy pozwoliły w każdym zbiorze danych dla lat 2010-2016 zaobserwować istotne zależności oraz oszacować wartości poszczególnych wskaźników, plasujące dany kraj przynajmniej w połowie rankingu względem danego wskaźnika.

Analizy pozwoliły sformułować następujące wnioski:

1. Przekroczenie wartości $1 \%$ PKB wydatków przedsiębiorstw na B+R powoduje osiągnięcie co najmniej wartości mediany dla wskaźnika odsetek przedsiębiorstw sektora MSP wdrażających innowacje.

2. Liczba patentów na mieszkańca w UE zależy prawie liniowo od wydatków przedsiębiorstw na $\mathrm{B}+\mathrm{R}$, ale nie zależy od wydatków publicznych na ten cel.

3. Przekroczenie $2 \%$ PKB wydatków przedsiębiorstw na $B+R$ jednocześnie stanowi uzyskanie co najmniej siedmiu patentów na miliard osób.

4. Przekroczenie poziomu $1 \%$ wydatków na PKB w przedsiębiorstwach prowadzi do osiągnięcia co najmniej wartości mediany w zakresie odsetka MSP wdrażających innowacje produktowe albo procesowe.

5. Wzrost liczby pracowników zaangażowanych w działania i procesy oparte na wiedzy powoduje również wzrost wartości MSP wdrażających innowacje.

6. Z rozkładu wartości można zaobserwować prawie liniową zależność pomiędzy wskaźnikiem odsetek przedsiębiorstw sektora MSP wdrażających innowacje oraz odsetkiem przedsiębiorstw sektora MSP wdrażających innowacje produktowe albo procesowe.

W analizie uwzględniono dla porównania (mimo braku istotnych zależności) wartości wskaźników w korelacji z publicznymi wydatkami na B+R.

Wyraźnie zaznacza się dodatnia zależność między liczbą zgłoszeń patentowych w trybie PCT na mld PKB a wydatkami na B+R, przy czym zależność prawie liniowa występuje dla wydatków ponoszonych przez przedsiębiorstwa. Skupienie większej części krajów w dolnej części wykresu dotyczącego wydatków publicznych na B+R wskazuje, że wydatki publiczne w mniejszym stopniu przekładają się na zgłoszenia patentowe.

Rysuje się dodatnia zależność między wydatkami przedsiębiorstw na $\mathrm{B}+\mathrm{R}$ a odsetkiem firm sektora MSP wdrażających innowacje w przypadku wydatków przedsiębiorstw (choć nie tak ścisła jak w przypadku zależności z liczbą zgłoszeń patentowych). 
Tab. 1. Wydatki przedsiębiorstw i publiczne na B+R w \% PKB a liczba zgłoszeń patentowych w trybie PCT na mld PKB w latach 2010-2016

\begin{tabular}{|c|c|c|}
\hline Rok & $\begin{array}{l}\text { Wydatki przedsiębiorstw na B+R w \% PKB } \\
\text { a liczba zgłoszeń patentowych } \\
\text { w trybie PCT na mld PKB }\end{array}$ & $\begin{array}{c}\text { Wydatki publiczne na B+R w \% PKB a liczba } \\
\text { zgłoszeń patentowych } \\
\text { w trybie PCT na mld PKB }\end{array}$ \\
\hline $\begin{array}{c}2010 \\
2 a)\end{array}$ & 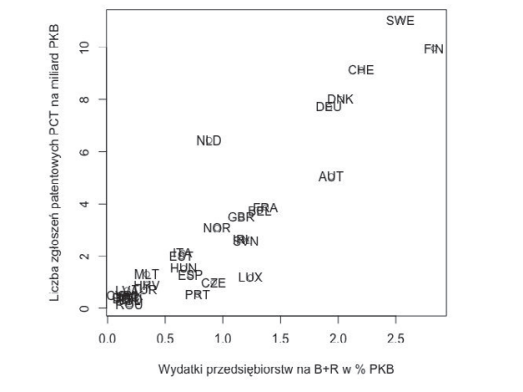 & 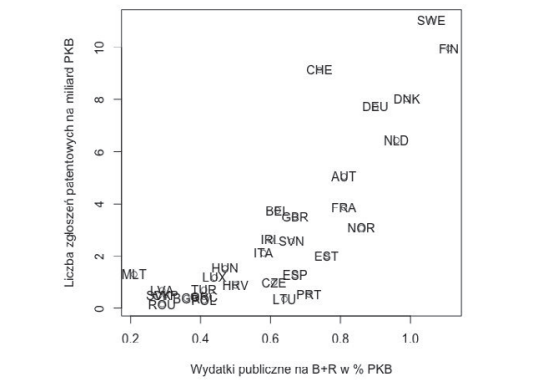 \\
\hline $\begin{array}{c}2012 \\
2 \mathrm{~b})\end{array}$ & 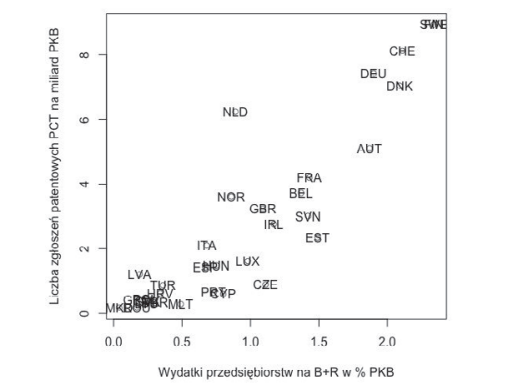 & 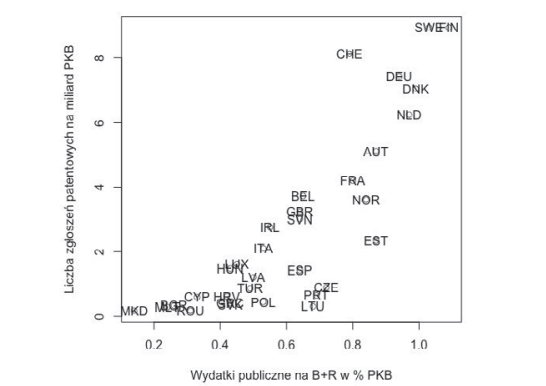 \\
\hline $\begin{array}{c}2014 \\
2 c)\end{array}$ & 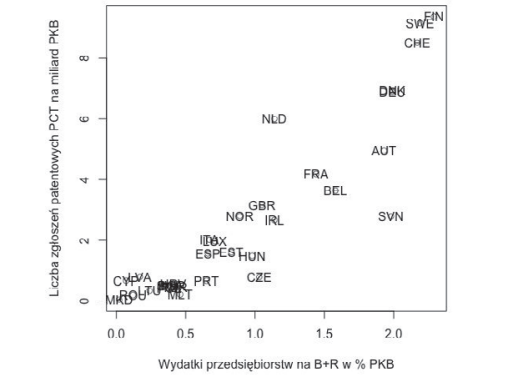 & 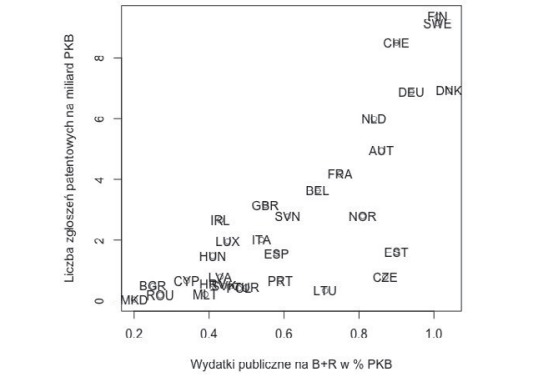 \\
\hline $\begin{array}{c}2016 \\
2 \mathrm{~d})\end{array}$ & 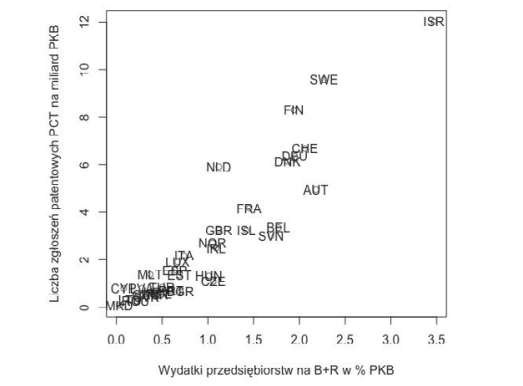 & 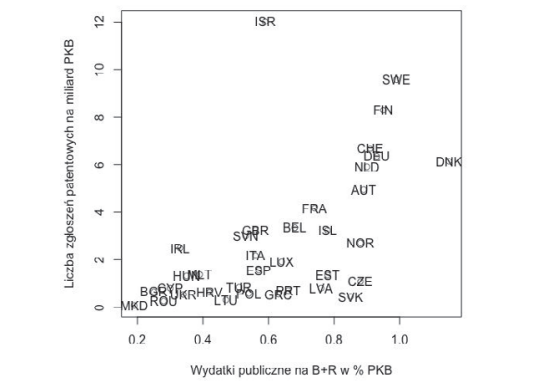 \\
\hline
\end{tabular}

Źródło: opracowanie własne na podstawie badań 
Tab. 2. Wydatki przedsiębiorstw i publiczne na działalność B+R w \% PKB a MSP wdrażające innowacje (w \% MSP) w latach 2010-2016

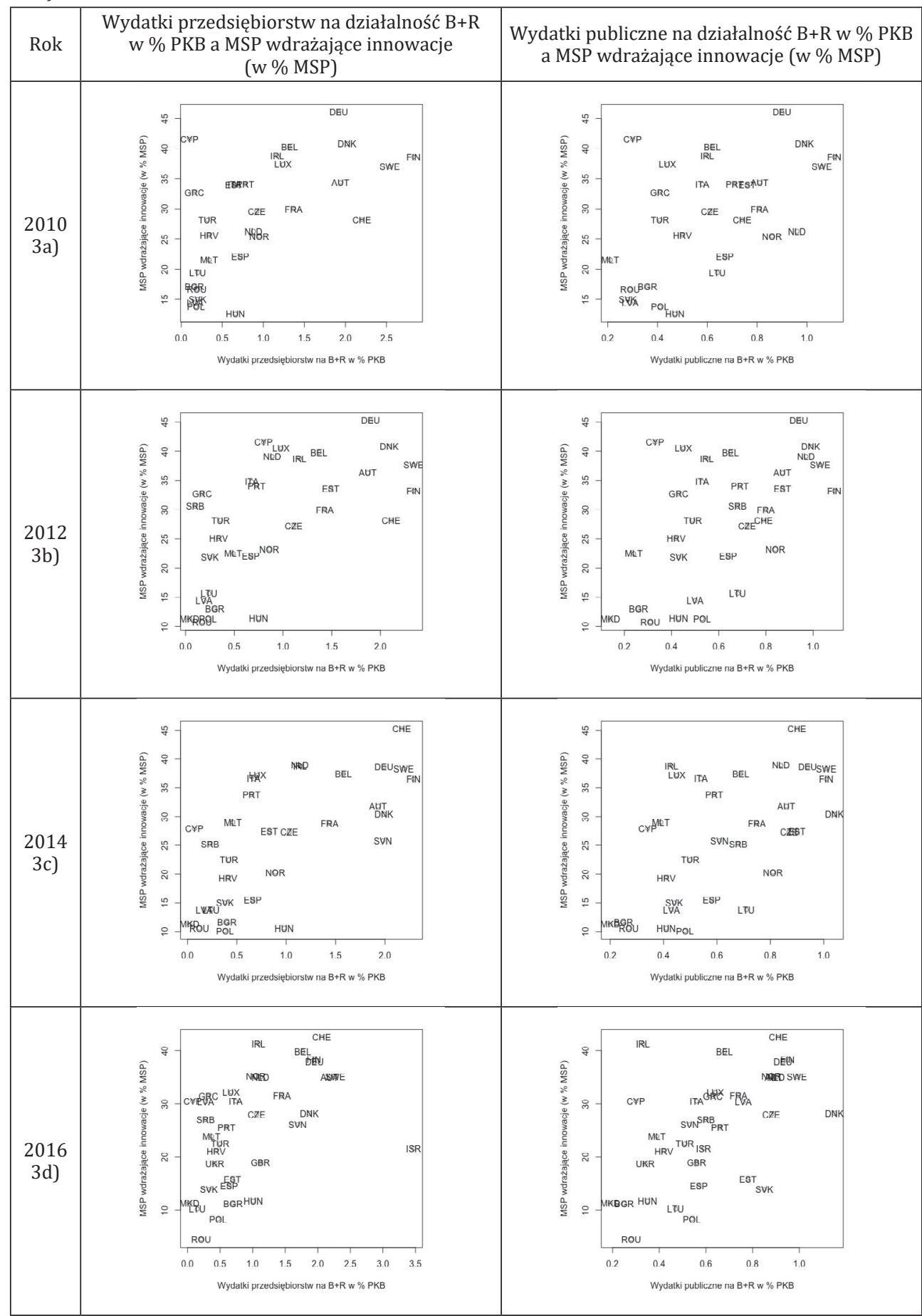

Źródło: opracowanie własne na podstawie badań 
Tab. 3. Wydatki przedsiębiorstw i publiczne na działalność B+R w \% PKB a udział MSP wprowadzających innowacje produktowe lub procesowe w latach 2010-2016

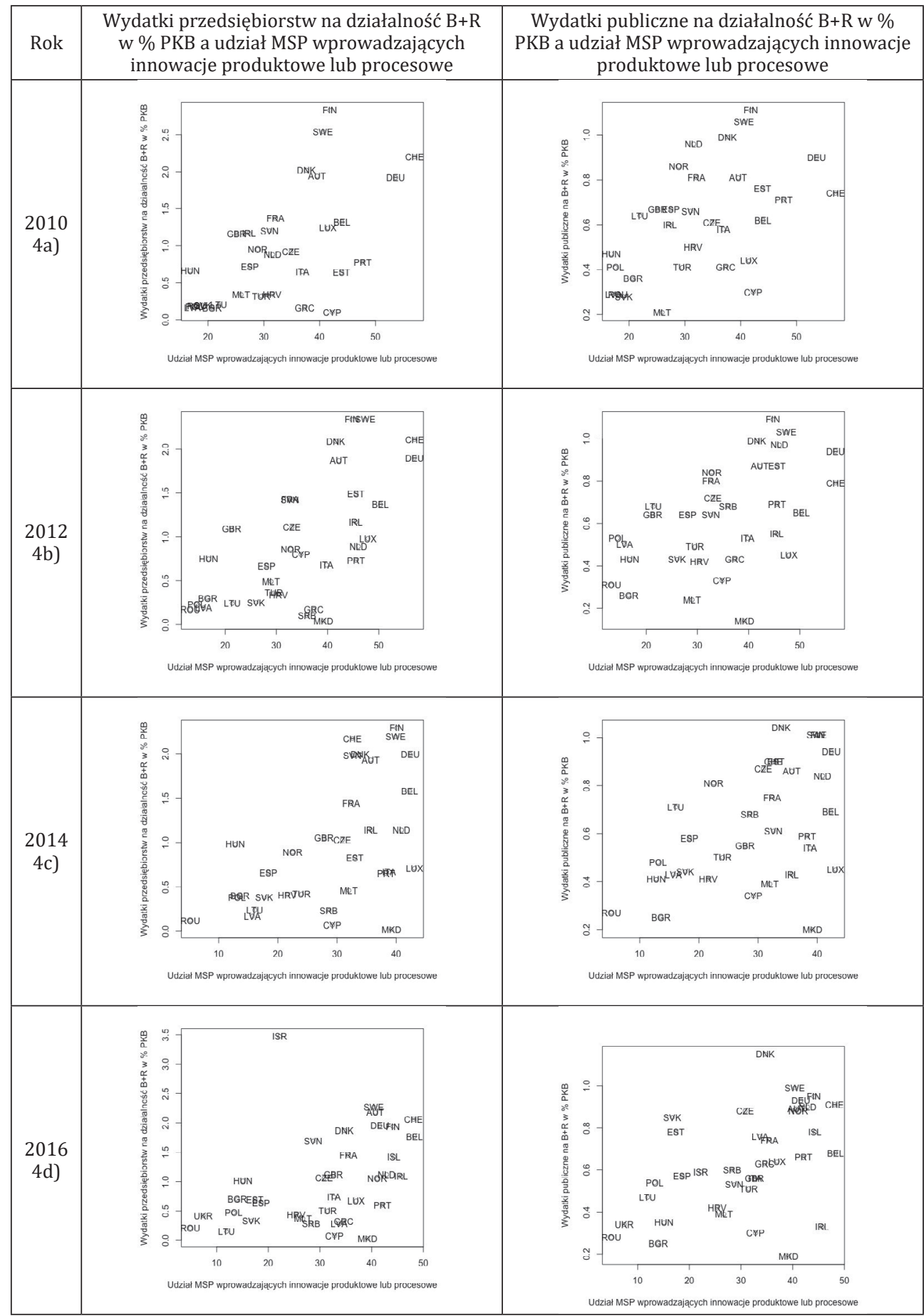

Źródło: opracowanie własne na podstawie badań 
Tab. 4. Udział zatrudnienia w branżach wiedzochłonnych a MSP wdrażające innowacje oraz MSP wdrażające innowacje (w \% MSP) a udział MSP wprowadzających innowacje produktowe lub procesowe w latach 2010-2016

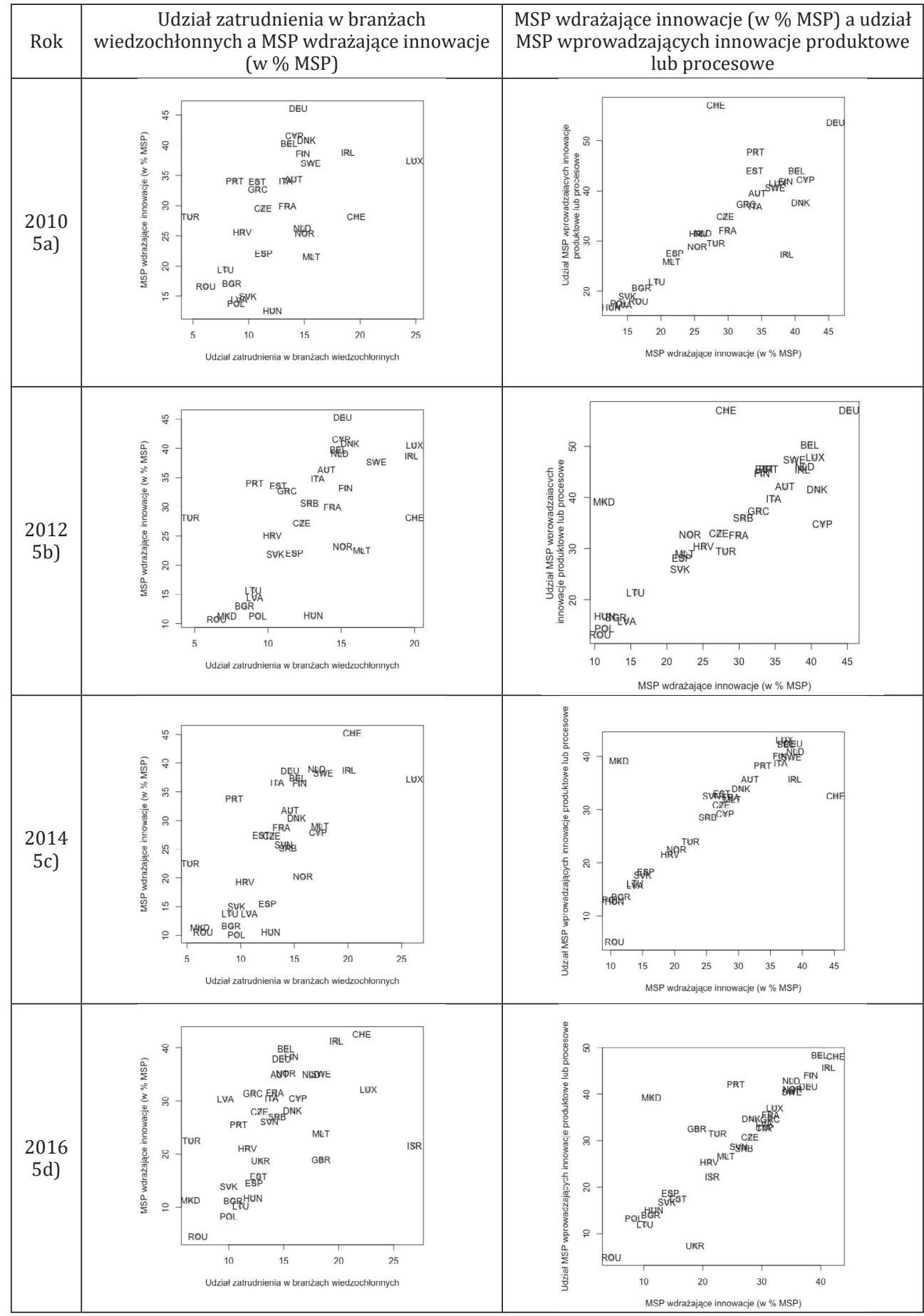

Źródło: opracowanie własne na podstawie badań 
Progresywny charakter krzywej, wokół której skupiają się poszczególne kraje, świadczy o tym, że innowacje w MSP nie zawsze wiążą się z dużymi nakładami na B+R. Natomiast między wydatkami publicznymi na $\mathrm{B}+\mathrm{R}$ a wdrażaniem innowacji w MSP niełatwo zauważyć istotne zależności.

Zależności między wydatkami na $\mathrm{B}+\mathrm{R}$ zarówno przedsiębiorstw, jak i instytucji publicznych a udziałem MSP wprowadzających innowacje produktowe lub procesowe są mniej ścisłe niż powyżej prezentowane relacje, aczkolwiek dodatnie zależności w przypadku wydatków przedsiębiorstw są łatwiej zauważalne. W krajach zamożnych przedsiębiorstwa zdecydowanie więcej wydają na B+R i relatywnie często sektor MSP wdraża innowacje produktowe lub procesowe, natomiast przykładowo w Grecji, Macedonii i Serbii, pomimo niskich wydatków na $\mathrm{B}+\mathrm{R}$, innowacje wdrażane są w MSP relatywnie często.

Zależności między MSP wdrażającymi innowacje a udziałem MSP wprowadzających innowacje produktowe lub procesowe z uwagi na współliniowość powinny zostać pominięte w prowadzeniu dalszych analiz.

Jeśli chodzi o zależności między udziałem zatrudnienia w branżach wiedzochłonnych a udziałem MSP wdrażających innowacje można zauważyć, że zatrudnienie specjalistów w branżach wiedzochłonnych w krajach mniej zamożnych (w tym w Polsce) nie zależy wprost proporcjonalnie od wdrażania innowacji w MSP.

\section{WNIOSKI}

W obecnych czasach poziom życia społeczeństwa każdego kraju zależy nie tyle od stopnia wykorzystania zaawansowanych technologii, co od zdolności do rozwoju potencjału naukowo-technicznego, umiejętności łączenia nauki z przemysłem, rozwoju przedsiębiorczości w sferze generowania nowych i konkurencyjnych rozwiązań oraz od aktywności w dążeniu do zwiększania zdolności do wdrażania innowacji. To właśnie bowiem innowacje w skali makroekonomicznej stanowią jeden z głównych czynników wzrostu gospodarczego, a w skali mikroekonomicznej przyczyniają się do wzrostu konkurencyjności pojedynczych przedsiębiorstw. Aby można było jednak monitorować, kontrolować i analizować poziom rozwoju we wskazanym obszarze, należy posłużyć się ujednoliconą metryką stanowiącą narzędzie statystycznego zarządzania procesem. Jednym z takich narzędzi jest Europejski Ranking Innowacyjności, umożliwiający analizę wyników osiągniętego poziomu innowacyjności w poszczególnych krajach członkowskich UE.

W przedstawionym w artykule procesie badawczym związane z tymi wskaźnikami dane stały się wektorami wejściowymi, które następnie - z zastosowaniem autorskiego narzędzia informatycznego doboru najlepszych modeli rozwiązań - zostały poddane analizie na różnych poziomach szczegółowości, aby osiągnąć wartość, którą była oczekiwana wiedza użyteczna.

Zaimplementowana w zastosowanym oprogramowaniu funkcja analizy współczynnika determinacji badanych zbiorów danych podała informację, że do procesu selekcji, grupowania, wyselekcjonowania właściwych atrybutów wektorów danych oraz ich zestawienia korelacyjnego najbardziej optymalnym modelem będzie w tym przypadku liniowy model regresji przestrzennej struktury zależności zmiennych. Zastosowanie tego podejścia pozwoliło na otrzymanie macierzy wynikowej w postaci wszystkich par zmiennych wzajemnie od siebie zależnych. Wykorzystane w badaniu 
zbiory danych nie miały co prawda znaczącego rozmiaru, ale zastosowanie użytego narzędzia informatycznego daje możliwość automatycznego wyodrębnienia podzbioru zmiennych użytecznych dla zdefiniowanej dziedziny rozwiązań z całego dostępnego zbioru danych wejściowych, niezależnie od wielkości tego zbioru. W procesie analizy danych aplikacja dokonuje również wyboru metody estymacji współczynników korelacji zmiennych. Zaimplementowane metody dotyczą metody najmniejszych kwadratów oraz metody największej wiarygodności. Dzięki temu, jeżeli zostaną wykryte potęgowe zależności pomiędzy zmiennymi, to nastąpi również analiza zależności pomiędzy logarytmami tych zmiennych. Pozwala to na analizę danych, dla których wariancja ocen współczynników jest zarówno mała, jak i duża.

Analiza wyników w odniesieniu do wszystkich skorelowanych zmiennych pozwala stwierdzić, że rzeczywisty wzrost innowacyjności można osiągnąć poprzez zwiększoną aktywność sektora prywatnego w tej dziedzinie. Planując kontynuację badań, autorzy zamierzają poddać analizie również zależności zmiennej objaśnianej od dwóch lub większej ilości zmiennych jakościowych, tak aby można było rozpatrzeć wszystkie efekty addytywne i istniejące interakcje.

\section{Literatura \\ References}

Birch, D.L. (1987). Job Creation in America. New York: Free Press.

Cincera, M., Czarnitzki, D., Thorwarth, S. (2011). Efficiency of public spending in support of R\&D activities. W: Reflets perspectives de la vie économique, 1-2 (tom L). De Boeck Supérieur, 131-139.

Czerniak, J. (2013). Polityka innowacyjna w Polsce. Analiza i proponowane kierunki zmian. Warszawa: Difin.

Drucker, P. (1992). Innowacje i przedsiębiorczość. Praktyka i zasady. Warszawa: Polskie Wydawnictwo Ekonomiczne.

Dynamising National Innovation Systems (2002) (2017, 19 grudnia). OECD. Pozyskano z https:// www.oecd-ilibrary.org/industry-and-services/dynamising-national-innovation-systems_ 9789264194465-en

Efron, B., Hastie, T., Johnstone, I., Tibshirani, R. (2004). Least angle regression. Annals of Statistic, 32(2), 407-499.

European Innovation Scoreboard (2017, 19 grudnia). Pozyskano z http://ec.europa.eu/growth/ industry/innovation/facts-figures/scoreboards_en

Frascati Manual. Proposed standard Practice for Surveys on Research and Experimental Development, (2002) (2017, 19 grudnia). OECD. Pozyskano z http://www.oecd.org/sti/ inno/frascatimanualproposedstandardpracticeforsurveysonresearchandexperimentaldevelopment6thedition.htm

Global Creativity Index 2015 (2015) (2017, 19 grudnia). Martin Prosperity Institute. Pozyskano z http://martinprosperity.org/media/Global-Creativity-Index-2015.pdf

Global Innovation Index 2016 (2016) (2017, 19 grudnia). Winning with Global Innovation. Johnson Cornell University. INSEAD The Business School for the World, World Intellectual Property Organization. Pozyskano z http://www.wipo.int/edocs/pubdocs/en/wipo_pub_gii_2016. pdf

Gnot, S. (1994). Estymacja komponentów wariacyjnych $w$ modelach liniowych. Warszawa: Wydawnictwa Naukowo-Techniczne.

Griffin, R.W. (1996). Podstawy zarządzania organizacjami. Warszawa: Wydawnictwo Naukowe PWN.

Grosse, T.G. (2002). Przegląd koncepcji teoretycznych rozwoju regionalnego. Studia Regionalne i Lokalne, 1(8). 
Guellec, D., van Pottelsberghe de la Potterie, B. (1999). Does government support stimulate private R\&D? OECD. Economic Studies, 29, 95-122.

Janasz, W., Kozioł, K. (2007). Determinanty działalności innowacyjnej przedsiębiorstw. Warszawa: Polskie Wydawnictwa Ekonomiczne, 43-44.

Jasiński, A.H. (1998). Innowacje techniczne a działalność marketingowa. Warszawa: Wyższa Szkoła Przedsiębiorczości i Zarządzania, 13-14.

Karlik, M. (2012). Zarządzanie innowacjami w przedsiębiorstwie. Warszawa: Wydawnictwo Poltext.

Kasprzyk, S. (1980). Innowacje od koncepcji do produkcji. Warszawa: Instytut Wydawniczy CRZZ.

Komunikat Komisji Europa 2020. Strategia na rzecz inteligentnego i zrównoważonego rozwoju sprzyjającego włączeniu społecznemu (2010) (2017, 19 grudnia). Komisja Europejska. KOM 2020. Bruksela.

Kotler, Ph. (1994). Marketing. Analiza, planowanie, wdrażanie i kontrola. Warszawa: Gebethner i Ska, 15-28.

Kozłowski, J. (2015). Innovation indices: the need for positioning them where they properly belong. Scientometrics, 104(3), 609-628.

Managing National Innovation Systems (1999) (2017, 19 grudnia). OECD. Pozyskano z https:// www.oecd-ilibrary.org/industry-and-services/managing-national-innovation-systems_9789264189416-en

Nowak, P. (2012). Poziom innowacyjności polskiej gospodarki na tle krajów UE. Prace Komisji Geografii Przemysłu Polskiego Towarzystwa Geograficznego, 19, 153-168.

Oslo Manual. Guidelines for Collecting and Interpreting Innovation Data (2005) (2017, 19 grudnia). OECD. Pozyskano z http://www.oecd.org/sti/inno/oslomanualguidelinesforcollectingandinterpretinginnovationdata3rdedition.htm

Polarczyk, K. (2007). Wydatki publiczne w Polsce na tle państw Unii Europejskiej, Biuro Analiz Sejmowych, 22, 1-2.

Pomykalski, A. (2001), Zarzq̨dzanie innowacjami. Warszawa-Łódź: Wydawnictwo Naukowe PWE.

Schumpeter, J.A. (1960). Teoria rozwoju gospodarczego, Warszawa: PWN, 104.

Shirley, P. (1994). Venture Capital. Fiscal Studies, 2(15), 98-104.

Skica, T. (2011). Efektywność wydatkowania publicznego w Polsce. Zeszyty Naukowe Instytutu Ekonomii i Zarzq̨dzania Politechniki Koszalińskiej, 14, 115-129.

Śpionek, A. (2010). Innowacyjność - definicja, ogólne informacje o innowacyjności w regionie. W: P. Nowak (red.). Innowacje 2010. Łódź: Departament Infrastruktury, 11-17.

The Innovation Policy Platform (2017, 19 grudnia). Pozyskano z www.innovationpolicyplatform. org

Tylec, T. (2015). Wielkość i struktura finansowania działalności badawczo-rozwojowej w krajach rozwiniętych gospodarczo. Wnioski dla Polski. The Central European Journal of Social Sciences and Humanities, 210, 242-253.

Weresa, M. (2002). Wpływ handlu zagranicznego i inwestycji bezpośrednich na innowacyjność polskiej gospodarki. Warszawa: Szkoła Główna Handlowa.

Weresa, M. (2012). Systemy innowacyjne a konkurencyjność w świetle wybranych koncepcji teoretycznych. Warszawa: Kolegium Gospodarki Światowej, Szkoła Główna Handlowa.

Weresa, M. (2014). Polityka innowacyjna. Warszawa: Wydawnictwo Naukowe PWN.

Zegarowicz, Ł., Wildowicz-Giegiel, A. (2017). Wspieranie działalności B+R a efekt wypychania w krajach OECD. Prace Naukowe Uniwersytetu Ekonomicznego we Wrocławiu, 475, 415-428.

Zioło, Z., Rachwał, T. (red.) (2012). Wpływ innowacyjności na rozwój przedsiębiorstw. Prace Komisji Geografii Przemysłu Polskiego Towarzystwa Geograficznego, 20.

Marta Czyżewska, dr nauk ekonomicznych w zakresie ekonomii, adiunkt w Katedrze Ekonomii i Polityki Gospodarczej w Instytucie Politologii Uniwersytetu Pedagogicznego im. Komisji Edukacji Narodowej w Krakowie. Były dyrektor Centrum Innowacji i Przedsiębiorczości w WSIiZ w Rzeszowie. Badania, jakie w ostatnim czasie prowadzi, skupiają się wokół determinant innowacyjności i przedsiębiorczości jako kluczowych czynników warunkujących rozwój gospodarek. Autorka lub współautorka książek i artykułów nt. venture capital, innowacyjności i przedsiębiorczości. 
Marta Czyżewska, Ph.D. in economics in the field of economics, Assistant Professor at the Department of Economics and Economic Policy, The Institute of Political Science at Pedagogical University in Cracow. Former Director of Innovativeness and Entrepreneurhsip Center at UITM in Rzeszow. Her research focuses recently on determinants of innovativeness and entrepreneurship as key factors underlying economies development. Author and co-author of books and articles on venture capital, innovativeness and entrepreneurship.

\title{
Adres/address:
}

\author{
Uniwersytet Pedagogiczny w Krakowie \\ Instytut Prawa, Administracji i Ekonomii \\ Katedra Ekonomii i Polityki Gospodarczej \\ ul. Podchorążych 2/234, 30-084 Kraków, Polska \\ e-mail: mczyzewska@up.krakow.pl
}

Arkadiusz Lewicki, dr inż., doktor nauk technicznych w dziedzinie informatyki, zastępca kierownika Katedry Zastosowań Systemów Informatycznych Wyższej Szkoły Informatyki i Zarządzania w Rzeszowie. Jego badania dotyczą przede wszystkim inteligencji roju, sieci neuronowych i strategii ewolucyjnych. Obecnie prowadzi również badania w obszarze zastosowania metaheurystyk dla metod optymalizacji problemów natury kombinatorycznej.

Arkadiusz Lewicki, Ph.D. in technical sciences in the field of computer science, Deputy Head of the Chair of Information Systems Applications in Department of Applied Informatics at the University of Information Technology and Management in Rzeszow. His research focuses mainly on swarm intelligence, neural networks and evolutionary computation. Current research interests of dr. Lewicki include also metaheuristics and local search methods for combinatorial optimization and parallel and distributed computing.

\section{Adres/address:}

Wyższa Szkoła Informatyki i Zarządzania z siedzibą w Rzeszowie Wydział Informatyki Stosowanej Katedra Zastosowań Systemów Informatycznych ul. Sucharskiego 2, 35-225 Rzeszów

e-mail: alewicki@wsiz.rzeszow.pl 